\title{
The Sword in the Stone
}

Together with the edited book, 'Milestones in State Aid Case Law - EStAL's First Fifteen Years in Perspective', this issue marks the approaching close of EStAL's $15^{\text {th }}$ anniversary year. For this occasion, it seems appropriate that both the foreword of the edited book and this editorial reflect on the evolutionary nature of State aid policy. There is no better starting point for this exercise than the birth of EU State aid control.

Already in the fifties, the EU founding fathers understood that pressures to subsidise would arise during the process of economic integration and that a targeted policy was necessary. In the current numbering, Article 107(1) TFEU ${ }^{1}$ contains a general prohibition of State aid. Paragraphs 107(2) and 107(3) and Article 106(2) and 93 deal with potential derogations or exceptions, topics for which State aid could be allowed. The general prohibition and the potential exceptions, already included in the Treaty of Rome, constituted only the beginning and State aid policy has evolved ever since.

Shortly after the Treaty of Rome, Disney released its film 'The Sword in the Stone' fittingly laying out the path to maturity and wisdom. As young Wart, or officially Arthur, found his tutor in Merlin, DG Competition was taken under the wing of the Court of Justice and matured ever since the introduction of the primary rules. As Arthur was, during darker times, transformed into a fish by Merlin, the broad prohibition and potential exceptions were over the years fine-tuned and interpreted in, for example, regulations, guidelines and case law. Clarifications indeed result constantly from daily practice, but sometimes also from well-steered reform projects. Arthur was subsequently transformed into a squirrel and a bird, and so State aid policy underwent two remarkable transformations since the 2000 s.

The squirrel. The Commission's State Aid Action Plan (SAAP) ${ }^{2}$ for the period 2005 until 2009 set out towards "less and better targeted State aid" and the creation of a more predictable framework and endeavoured to contribute to the Lisbon objectives. The reform priorities work towards less aid that is more efficiently applied, but also towards better procedures and enforcement and increased transparency. The balancing test should allow the Commission to analyse positive effects of a proposed aid and to check whether they outweigh potential negative consequences, such as a distortion of competition. SAAP was also supposed to bring a more interdisciplinary perspective. We vividly remember the seminal papers on "the economic framework" ${ }^{\prime 3}$ and on "the more refined economics approach". ${ }^{4}$ We all agree after SAAP that economics is as important to State aid as the wand is to the wizard. However, as another Disney's character showed us, using the wand without knowing properly the rules may sometimes lead to catastrophic situations. ${ }^{5}$ That is why economics can only be applied within the limits of the law.

DOI: $10.21552 / \mathrm{estal} / 2017 / 4 / 2$

Consolidated Version of the Treaty on the Functioning of the European Union [2012] OJ C 326/47.

European Commission, State Aid Action Plan. Less and better targeted State aid: a roadmap for State aid reform 2005-2009, 2005, available at <http://ec.europa.eu/competition/state_aid/reform/archive.html> (last accessed on 20 October 2017).

3 HW Friederiszick, LH Röller and V Verouden, 'European State aid control: an economic framework' in P Buccirossi (ed.), Handbook of Antitrust Economics (Cambridge: MIT Press 2008).

4 D Neven and V Verouden, 'Towards a more refined economic approach in State aid control' in W Mederer, N. Pesaresi and M Van Hoof (eds), EU Competition Law, Volume IV: State aid (Deventer: Claeys and Casteels 2008).

5 Walt Disney's "Fantasia 1940 - The Sorcerer's Apprentice", music by Paul Dukas. 
The bird. Young Arthur ventured into a second large evolutionary wave with the introduction of the State Aid Modernisation (SAM) initiative ${ }^{6}$ in 2012. As a dynamic and competitive internal market fosters growth, SAM tried to change State aid control towards 'big on big and small on small', where the Commission's efforts could in theory be focused on the cases with the largest potential impact on the internal market. In addition, SAM's objective was to streamline the rules and to enable faster decision making. Until 2014, State aid policy was mainly limited to ex ante control of aid measures, i.e. the Commission judged whether an aid was deemed to be compatible with the internal market before it was put into effect. SAM, and the ensuing revision of the GBER, however, have also introduced ex post evaluation. This follows mainly from the extension of the GBER as more responsibility is placed with the Member States. This constitutes a sizeable gamble, for which the logical and legal compatibility with the State aid rules is not entirely clear. This requires, at minimum, some counterweight to ensure that the rules are complied with and that a level playing field is safeguarded. Evaluation is an appropriate instrument to complement monitoring and reporting efforts. This extra control is an imperative step in the coming of age of State aid policy as evaluation contributes to a closed policy cycle, where a learning process contributes to the taking off of improved future policy. Time will tell whether the well-intentioned young Arthur has gotten it entirely right with SAM or whether certain parts will need to be fine-tuned following Merlin's intervention.

Where SAAP and SAM indeed represent larger waves in the evolution of State aid policy, all around the notion of 'compatibility', numerous and probably more important clarifications have resulted from case law on the notion of State aid. The importance of the case law for the evolution of State aid control can hardly be exaggerated. In our opinion, it constitutes a treasure of legal wisdom that is also practically relevant. Without providing an exhaustive list, several leading cases directly come to mind: e.g. the landmark case PreussenElektra ${ }^{7}$ on the meaning of State resources, but also Stardust $t^{8}$ on measures that are imputable to the State. Then, the milestone Altmark $^{9}$ properly clarified the conditions for a public service compensation not to constitute State aid. Ryanair Charlero $i^{10}$ did not only shape later aviation guidelines, but also clarified the nature of economic activities and the use of the market economy operator test. Again later, Athinaïki Techniki ${ }^{11}$ shed light on the status of complainants in State aid cases. Deutsche Lufthansa ${ }^{12}$ confronted the interplay between State aid investigations and national court proceedings. After that, World Duty Free Group ${ }^{13}$ astounded many of us with its interpretation of selectivity in tax measures.

We clearly see the similarities with many of life's lessons that also young Arthur had to learn. It is imperative to plan the future and find direction, while not losing sight of the big-

6 European Commission, State Aid Modernisation, 2012, available at <http://ec.europa.eu/competition/state_aid/modernisation/index_en.html> (last accessed on 20 October 2017).

7 Case C-379/98 PreussenElektra AG v. Schleswag AG [2001] ECLI-160.

8 Case C-482/99 French Republic v Commission of the European Communities [2002] ECLI-294.

9 Case C-280/00 Altmark Trans GmbH and Regierungspräsidium Magdeburg v Nahverkehrsgesellschaft Altmark GmbH, and Oberbundesanwalt beim Bundesverwaltungsgericht [2003] ECLI-415.

10 Case T-196/04 Ryanair v Commission [2008] ECLI-585.

11 Cases C-521/06P Athinaïki Techniki AE v Commission of the European Communities [2008] ECLI-422 and C-362/09P Athinaiki Techniki AE v European Commission [2010] ECLI-783.

12 Case C-284/12 Deutsche Lufthansa v Flughafen Frankfurt Hahn [2013] ECLI-755.

13 Joined Cases C-20/15P and C21/15P European Commission v World Duty Free Group, formerly Autogrill España SA (C-20/15 P), Banco Santander SA, Santusa Holding SL (C-21/15 P), judgment of 21 December 2016, ECLI-624. 
ger picture. It is not wise to put too much faith in a quick fix, neither should we always trust in luck (even the Commission's magic cannot solve all problems). Sometimes, it is up to you how far you want to go. Remember, if you do not try, you will never find out whether it would have worked. But, whatever the reasoning you decide to follow, please always stay polite. It is left to the reader's personal interpretation to find the matching cases for these life lessons. Mostly, multiple answers will prove to be correct.

For the occasion of EStAL's $15^{\text {th }}$ birthday, 40 State aid aficionados share a current perspective on 32 of these most important State aid judgements in a new edited book. The analysis of several landmark cases indeed clearly demonstrates the evolution of State aid policy, not only in its clarification of concepts and rules, but also regarding the topics of cases that are dealt with. This evolution is fundamentally entwined with the broader picture, the European Integration project itself.

It was in 2002, that Andreas Bartosch and Wolfgang Andreae shared the opinion that the State aid scene might benefit from a platform that would regularly bring the State aid family together for an exchange of insights and to enable the dissemination of information between policy, courts, private practice, industry and academia. They ambitiously started the European State Aid Law Quarterly (EStAL) and the European State Aid Law Institute (EStALI). Not only State aid policy, but also EStAL and EStALI have evolved within the changing environment of scientific publishing. It is partly due to the evolutionary nature of State aid control that a platform such as EStAL generates added value by enabling all stakeholders to continuously share and confront ideas.

In conclusion, congratulations to EStAL for taking on this role for more than 15 years. And compliments and gratitude to all who contribute and transform a means into a wealth of information where new ideas can thrive and in their turn, contribute to an improved State aid policy and practice. We sincerely hope that our combined efforts will enable the platform to continue to blossom in the years to come. May EStAL continue to facilitate the dissemination of knowledge and wisdom, enabling us to take Excalibur from its stone and anvil when guidance is needed. Most likely not to rule England, but to come to a balanced decision and correct advice in all State aid cases that cross our path.

Make a wish!

Caroline Buts and José Luis Buendía Sierra 